${ }^{5}$ K. H. Jack: Binary and Ternary Interstitial Alloys II. Proceedings Royal Society (1948) 195A, pp. 41-45. ${ }^{6} \mathrm{R}$. Kiessling: The Borides of Some Transition Metals. Journal Electrochemical Society (1951) 98, pp. 166-169.

${ }^{7}$ C. Guillaud and J. Wyart: Propriétés magnetiques des Azotures de Manganese. Comptes Rendus (1946) 222, pp. 71-73.

${ }^{8}$ C. Guillaud: Variation Thermique de l'Aimantation Spontanée. Comptes Rendus (1946) 223, pp. 1110-1112.

${ }^{\circ} \mathrm{L}$. Pauling: Electron Transfer in Intermetallic Compounds. Proceedings National Academy of Sciences (1950) 36, pp. 533-538.

${ }^{10}$ A. F. Wells: Structural Inorganic Chemistry. (1950) Oxford. Clarendon Press.

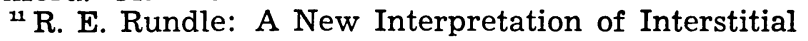

Compounds-Metallic Carbides, Nitrides, and Oxides of Composition MX. Acta Crystallographica (1948) I, pp. 180-187.

${ }^{12} \mathrm{~W}$. Sucksmith: The Measurement of Magnetic Saturation Intensities at Different Temperatures. Proceedings Royal Society (1939) 170A, pp. 551-560.

${ }^{13} \mathrm{~K}$. H. Jack: Unpublished research.

${ }^{11} \mathrm{P}$. Dayal and L. S. Darken: Migration of Carbon in Steel Under the Influence of Direct Current. Trans. AIME (1950) 188, pp. 1156-1158; Journal of Metals (September 1950).

${ }^{15}$ H. P. Myers and W. Sucksmith: Spontaneous Magnetization of Cobalt. Proceedings Royal Society (1951) A20\%, pp. 427-446.

${ }^{10}$ R. M. Bozorth: Ferromagnetism. (1951) p. 867. New York. D. Van Nostrand Co. Inc.

Technical Note

\title{
Preliminary Investigation of the System Ti-Mg
}

\author{
by J. W. Fredrickson
}

V ERY little information is available in the literature concerning the solubility of magnesium in titanium. Aust and Pidgeon ${ }^{1}$ report the solubility of titanium in magnesium to be 0.0025 pct at $650^{\circ} \mathrm{C}$ and 0.015 pet at $850^{\circ} \mathrm{C}$. X-ray diffraction studies failed to detect any evidence of solid solubility. Based on the fact that the addition of titanium to magnesium increases the $c / a$ ratio of magnesium, Busk ${ }^{2}$ suggested that the $\mathrm{Mg}-\mathrm{Ti}$ system, like the $\mathrm{Mg}-\mathrm{Zr}$, is a peritectic. Eisenreich ${ }^{3}$ reported the solubility of titanium in magnesium to be 0.003 pct at $655^{\circ} \mathrm{C}$ and 0.064 pct at $760^{\circ} \mathrm{C}$. Removal of hydrogen from the melt increased the solubility of titanium to 0.115 pct at $800^{\circ} \mathrm{C}$. Eisenreich proposes a peritectic-type diagram for the high magnesium side of the system. Recent work ${ }^{4}$ with Ti-Mg diffusion couples indicate that the solid solubility of titanium in magnesium is extremely small and that there is limited solid solubility of magnesium in titanium.

Experimental work on the Ti-Mg system is complicated by the fact that the boiling point of magnesium is considerably below the melting point of titanium. Consequently, the usual alloying methods are impractical. Alloying was accomplished in this investigation by sheath-rolling compressed compacts. ${ }^{5}$

The alloys were made from titanium sponge and high purity magnesium. Chemical analysis of the sponge showed 0.04 pct $\mathrm{Mg},<0.005$ pct $\mathrm{Al},<0.001$ pet $\mathrm{Cu}, 0.05$ pet $\mathrm{Fe}, 0.022$ pet $\mathrm{Mn},<0.0025$ pet $\mathrm{Ni}$, 0.007 pet $\mathrm{Si},<0.005$ pet $\mathrm{V}$, and $<0.01$ pet $\mathrm{Zn}$.

All heat treating was conducted in a protective atmosphere by encapsulating the specimens in fused silica ampules under a partial pressure of helium. Equilibrium was achieved by holding the specimens at temperature for periods of 24 to $120 \mathrm{hr}$. The alloys were hot rolled, cold rolled, and annealed prior to solution heat treatment.

Fig. 1 shows the constitutional diagram obtained for the Ti-Mg system up to 1.5 pct $\mathrm{Mg}$. Oxygen was known to be present in the alloys; therefore, it is necessary to consider the alloys as ternary rather than binary and the diagram should be viewed as a plot of a section through the Ti-Mg-O system. Other investigators ${ }^{6}$ have shown that the addition of oxy-

J. W. FREDRICKSON, Member AIME, is associated with Metallurgical Laboratories, The Dow Chemical Co., Midland, Mich.

TN 259E. Manuscript, Oct. 29, 1954.

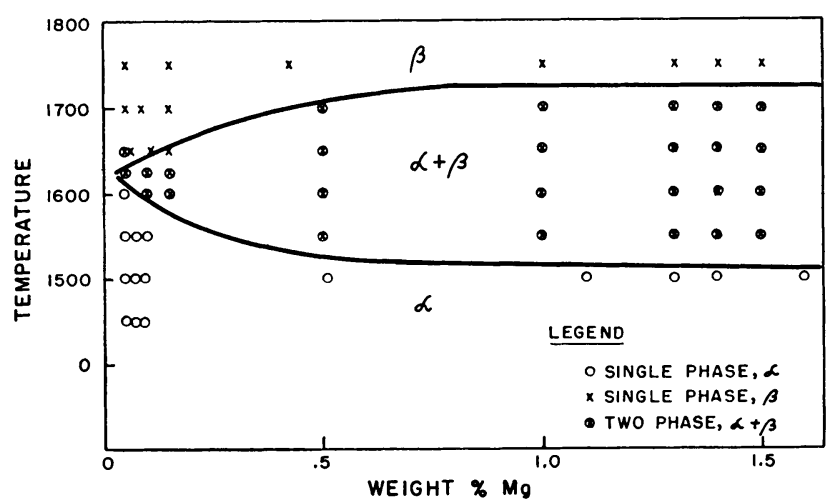

Fig. 1-Constitutional diagram obtained for the Ti-Mg system indicates that the addition of magnesium to titanium tends to stabilize the $\beta$ phase.

gen to titanium stabilizes the $\alpha$ phase. The data presented in Fig. 1 indicate that the addition of magnesium to titanium tends to stabilize the $\beta$ phase. Armour Research Foundation ${ }^{7}$ has shown that the addition of magnesium to zirconium lowers the $\alpha$ transus and is classified as a $\beta$ stabilizer in that system.

Magnesium is soluble in solid titanium to the extent of at least 1.5 pct in both the $\alpha$ and $\beta$ phases. No intermetallic compounds or magnesium-rich phases were observed either by light microscopy or X-ray diffraction. However, this does not negate the possibility that such phases exist at higher alloy concentrations.

\section{References}

${ }^{1}$ W. F. Aust and L. M. Pidgeon: Trans. AIME (1949) 185, pp. 585-587; Journal of METALS (September 1949).

${ }^{2}$ R. S. Busk: Trans. AIME (1950) 188, pp. 1460-1464; Journal of Metals (December 1950).

${ }^{3}$ H. Eisenreich: Metall (1953) 7, pp. 1003-1006.

${ }^{4}$ Rensselaer Polytechnic Institute. Progress Report No. 1 to Wright Air Development Center, WrightPatterson Air Force Base. Contract No. AF 33(616)2312 (Feb.-Apr. 1954).

${ }^{5} \mathrm{~J}$. R. Long: Titanium, Report of Symposium, Dec. 16, 1948. Sponsored by ONR (March 1949) pp. 27-46.

${ }^{6}$ E. S. Bumps, H. D. Kessler, and M. Hansen: Trans. ASM (1953) 45, pp. 1008-1024.

${ }^{7}$ Armour Research Foundation, Final Report to Atomic Energy Commission, Contract No. AT (11-1) 149 (Apr. 14, 1952). 